\title{
Effect of Heat Treatment on the Phase Composition, Microstructure and Mechanical Properties of $\mathrm{Al}_{0.6} \mathrm{CrFeCoNi}$ and $\mathrm{Al}_{0.6} \mathrm{CrFeCoNiSi}_{0.3}$ High-Entropy Alloys
}

\author{
Lijia Chen ${ }^{1,2}{ }^{\oplus}$, Kirsten Bobzin ${ }^{2}$, Zheng Zhou ${ }^{1, *}$, Lidong Zhao ${ }^{2}$, Mehmet Öte ${ }^{2}$, \\ Tim Königstein ${ }^{2}$, Zhen Tan ${ }^{1}$ and Dingyong $\mathrm{He}^{1}$ \\ 1 College of Materials Science and Engineering, Beijing University of Technology, Beijing 100124, China; \\ clj@emails.bjut.edu.cn (L.C.); zhen.tan@bjut.edu.cn (Z.T.); dyhe@bjut.edu.cn (D.H.) \\ 2 Surface Engineering Institute, RWTH Aachen University, 52072 Aachen, Germany; \\ info@iot.rwth-aachen.de (K.B.); zhao@iot.rwth-aachen.de (L.Z.); oete@iot.rwth-aachen.de (M.Ö.); \\ koenigstein@iot.rwth-aachen.de (T.K.) \\ * Correspondence: zhouzhengbjut@bjut.edu.cn; Tel.: +86-010-67392168
}

Received: 28 October 2018; Accepted: 16 November 2018; Published: 21 November 2018

\begin{abstract}
High-entropy alloys exhibit some interesting mechanical properties including an excellent resistance against softening at elevated temperatures. This gives high-entropy alloys (HEAs) great potential as new structural materials for high-temperature applications. In a previous study of the authors, oxidation behavior of $\mathrm{Al}_{0.6} \mathrm{CrFeCoNi}$ and $\mathrm{Al}_{0.6} \mathrm{CrFeCoNiSi}_{0.3}$ high-entropy alloys at $\mathrm{T}=800{ }^{\circ} \mathrm{C}, 900{ }^{\circ} \mathrm{C}$ and $1000{ }^{\circ} \mathrm{C}$ was investigated. Si-alloying was found to increase the oxidation resistance by promoting the formation of a continuous $\mathrm{Al}_{2} \mathrm{O}_{3}$ layer, avoiding the formation of $\mathrm{AlN}$ at $\mathrm{T}=800{ }^{\circ} \mathrm{C}$. Obvious phase changes were identified in the surface areas of both alloys after the oxidation experiments. However, the effects of heat treatment and Si-alloying on the phase transition in the bulk were not investigated yet. In this study, $\mathrm{Al}_{0.6} \mathrm{CrFeCoNi}$ and $\mathrm{Al}_{0.6} \mathrm{CrFeCoNiSi}_{0.3}$ high-entropy alloys were heat-treated at $\mathrm{T}=800{ }^{\circ} \mathrm{C}$ and $\mathrm{T}=1000{ }^{\circ} \mathrm{C}$ to investigate the effect of heat treatment on microstructure, phase composition and mechanical properties of both alloys. The results show that alloying $\mathrm{Al}_{0.6} \mathrm{CrFeCoNi}$ with $\mathrm{Si}$ caused a phase transition from dual phases consisting of BCC and FCC to a single BCC phase in an as-cast condition. Furthermore, increased hardness for as-cast and heat-treated samples compared with the $\mathrm{Al}_{0.6} \mathrm{CrFeCoNi}$ alloy was observed. In addition, the heat treatment facilitated the phase transition and the precipitation of the intermetallic phase, which resulted in the change of the mechanical properties of the alloys.
\end{abstract}

Keywords: high-entropy alloy; heat treatment; microstructure; phase composition

\section{Introduction}

High-entropy alloys (HEAs), which typically contain five or more metallic elements in equal or near-equal concentrations, have recently received great attention due to their unconventional phase compositions, typically with BCC or/and FCC crystal structures [1], and their very interesting properties [2-21]. Among the interesting properties, it is particularly the excellent resistance against softening at elevated temperatures that gives HEAs great potential as new structural materials for high-temperature applications. Besides the mechanical properties, the oxidation behavior of metallic alloys is an important property of structural materials with respect to applications at high-temperature. In a previous study [22], the oxidation behavior of two $\mathrm{HEAs}, \mathrm{Al}_{0.6} \mathrm{CrFeCoNi}$ and $\mathrm{Al}_{0.6} \mathrm{CrFeCoNiSi}_{0.3}$, was investigated at $\mathrm{T}=800{ }^{\circ} \mathrm{C}, \mathrm{T}=900^{\circ} \mathrm{C}$ and $\mathrm{T}=1000^{\circ} \mathrm{C}$ to evaluate the temperatures at which they 
are applicable without additional coating protection, and to determine the effect of Si-alloying thereon. It was found that $\mathrm{Si}$-alloying could increase the oxidation resistance by promoting the formation of a continuous $\mathrm{Al}_{2} \mathrm{O}_{3}$ layer, avoiding the formation of $\mathrm{AlN}$ at $\mathrm{T}=800{ }^{\circ} \mathrm{C}$ compared to the alloy $\mathrm{Al}_{0.6} \mathrm{CrFeCoNi}$. The analysis of the oxidized surface areas of both alloys revealed that in the test temperature range, phase changes occurred in the surface areas of both alloys. Although the chemical compositions in the surface areas of both alloys differed significantly from the original chemical compositions due to the oxidation, the phase transition from a single BCC phase in an as-cast condition to both $\mathrm{BCC}$ phase and $\mathrm{FCC}$ phase for $\mathrm{Al}_{0.6} \mathrm{CrFeCoNiSi}_{0.3}$ after the oxidation tests was characterized by the formation of a large amount of FCC phase. This indicates that the change in the chemical composition of the surface areas was not the only cause of the phase transition. This phase transition occurs within the alloy during the heat treatment under the same conditions as were used in the oxidation tests, i.e., the phase transition is a property of the alloy. In order to investigate the effect of heat treatment on phase transition as well as on microstructure and mechanical properties, both alloys were heat-treated at $\mathrm{T}=800^{\circ} \mathrm{C}$ and $\mathrm{T}=1000^{\circ} \mathrm{C}$ for $\mathrm{t}=100 \mathrm{~h}$ in this study. Phase composition, microstructure, indentation modulus and microhardness were analyzed and determined both in an as-cast condition as well as after the heat treatment by means of $X$-ray diffraction analysis, scanning electron microscopy (SEM) and indentation tests.

\section{Experimental}

A mixture of high-purity components (higher than $99.9 \mathrm{wt} \%$ ) was used to prepare the $\mathrm{Al}_{0.6} \mathrm{CrFeCoNi}$ and $\mathrm{Al}_{0.6} \mathrm{CrFeCoNiSi}_{0.3}$ HEA ingots. The mixed materials were melted by an arc in a water-cooled copper hearth in a Ti-gettered high-purity argon atmosphere. In the following, $\mathrm{Al}_{0.6} \mathrm{CrFeCoNi}$ and $\mathrm{Al}_{0.6} \mathrm{CrFeCoNiSi}_{0.3}$ will be referred to as $\mathrm{Al}_{0.6}$ and $\mathrm{Al}_{0.6} \mathrm{Si}_{0.3}$. Prior to the heat treatment experiments, specimens with a geometry of $\mathrm{V}=20 \times 20 \times 10 \mathrm{~mm}^{3}$ were prepared, ground and cleaned with ethanol under ultrasonic vibrations. The heat treatment tests were conducted under ambient air at $\mathrm{T}=800{ }^{\circ} \mathrm{C}$ and $1000{ }^{\circ} \mathrm{C}$ in a PKE 12-12 furnace (LAC, Rajhrad, Czech Republic) for $\mathrm{t}=100 \mathrm{~h}$; these conditions were used in the oxidation tests in the previous study [22]. After the heat treatment tests, the sample surfaces were ground, during which a thickness of at least $d=1 \mathrm{~mm}$ was taken off in order to ensure the removal of the oxide layer. Because the oxidation-effected surface areas were smaller than $\mathrm{d}=100 \mu \mathrm{m}$ [22], an effect of the oxidation on the chemical composition in the surface area of the samples after grinding can be excluded. The phase compositions were investigated via X-ray diffraction analysis using XRD 3000 (GE Inspection Technologies GmbH, Hürth, Germany) with a $\mathrm{Cu}$ target. The diffraction angles were set in a range from $2 \theta=20 \sim 90^{\circ}$ with a step width of $\Delta \theta=0.05^{\circ}$ and $\mathrm{t}=10 \mathrm{~s} / \mathrm{step}$. The microstructure of the HEAs in an as-cast condition as well as after the heat treatment was investigated using metallographically prepared samples by means of SEM by Carl Zeiss Microscopy GmbH, Germany equipped with an energy dispersive X-ray spectrometer (EDS, EDAX, Mahwah, NJ, USA). Furthermore, mapping measurements were conducted on the samples to determine the element distribution in the alloys. The Vickers hardness was measured using a Vickers tester (Buehler Ltd., Düsseldorf, Germany) with a load of $\mathrm{F}=49.1 \mathrm{~N}(5 \mathrm{~kg})$ and a dwell time of $\mathrm{t}=10 \mathrm{~s}$. Ten measurements were taken to calculate an average value. The Young's modulus was estimated using the equation $\mathrm{E}_{\mathrm{IT}}=\mathrm{E} \times\left(1-\mathrm{v}^{2}\right)\left(\mathrm{E}_{\mathrm{IT}}\right.$ : Indentation modulus, $\mathrm{E}$ : Young's modulus, $\mathrm{v}$ : Poisson's ratio). In this study, Poisson's ratio was set to $\mathrm{v}=0.3$ for both alloys. The indentation modulus was measured on the polished samples using the micro-indentation system Fischerscope HM2000 by Helmut Fischer GmbH (Sindelfingen-Maichingen, Germany) with a load of F $=1000 \mathrm{mN}$ and a dwell time of $t=20 \mathrm{~s}$. Under this load, homogenous indentations could be produced that were large enough to cover different phases. In addition to the indentation modulus, the elastic work $W_{\mathrm{e}}$ and the plastic work $\mathrm{W}_{\mathrm{p}}$ applied during the measurements were determined based on the force-displacement curve [23]. 


\section{Results and Discussion}

\subsection{Phase Compositions and Microstructures}

Figure 1 shows XRD diffraction patterns of $\mathrm{Al}_{0.6}$ and $\mathrm{Al}_{0.6} \mathrm{Si}_{0.3}$ in their as-cast states and after the heat treatment tests. It is recognizable that $\mathrm{Al}_{0.6}$ in its as-cast state exhibits BCC-type and FCC-type phases. The relative phase compositions are obtained by Rietveld analysis with XRD data and the results are shown in Table 1. The peak intensities of the FCC-type phase are significantly higher than those of the BCC-type phase, indicating a higher amount of the FCC-type phase compared to the BCC-type phase. Similar results were reported in [17,24-26]. $\mathrm{Al}_{0.6} \mathrm{Si}_{0.3}$, on the other hand, only exhibits a BCC-type phase in an as-cast state, showing that the Si-addition favors the formation of a BCC crystal structure. This was mainly attributed to the lower valence electron concentration in Si [27].

Table 1. Relative phase composition from Rietveld analysis with $\mathrm{XRD}$ data for $\mathrm{Al}_{0.6}$ and $\mathrm{Al}_{0.6} \mathrm{Si}_{0.3}$ samples.

\begin{tabular}{ccc}
\hline Sample & FCC (wt \%) & BCC (wt \%) \\
\hline $\mathrm{Al}_{0.6}$-as-cast & 100.0 & 59.1 \\
$\mathrm{Al}_{0.6}-800^{\circ} \mathrm{C}$ & 100.0 & 66.3 \\
$\mathrm{Al}_{0.6}-1000^{\circ} \mathrm{C}$ & 61.0 & 100.0 \\
$\mathrm{Al}_{0.6} \mathrm{Si}_{0.3}$-as-cast & - & 100.0 \\
$\mathrm{Al}_{0.6} \mathrm{Si}_{0.3}-800^{\circ} \mathrm{C}$ & 95.0 & 100.0 \\
$\mathrm{Al}_{0.6} \mathrm{Si}_{0.3}-1000^{\circ} \mathrm{C}$ & 59.8 & 100.0 \\
\hline
\end{tabular}
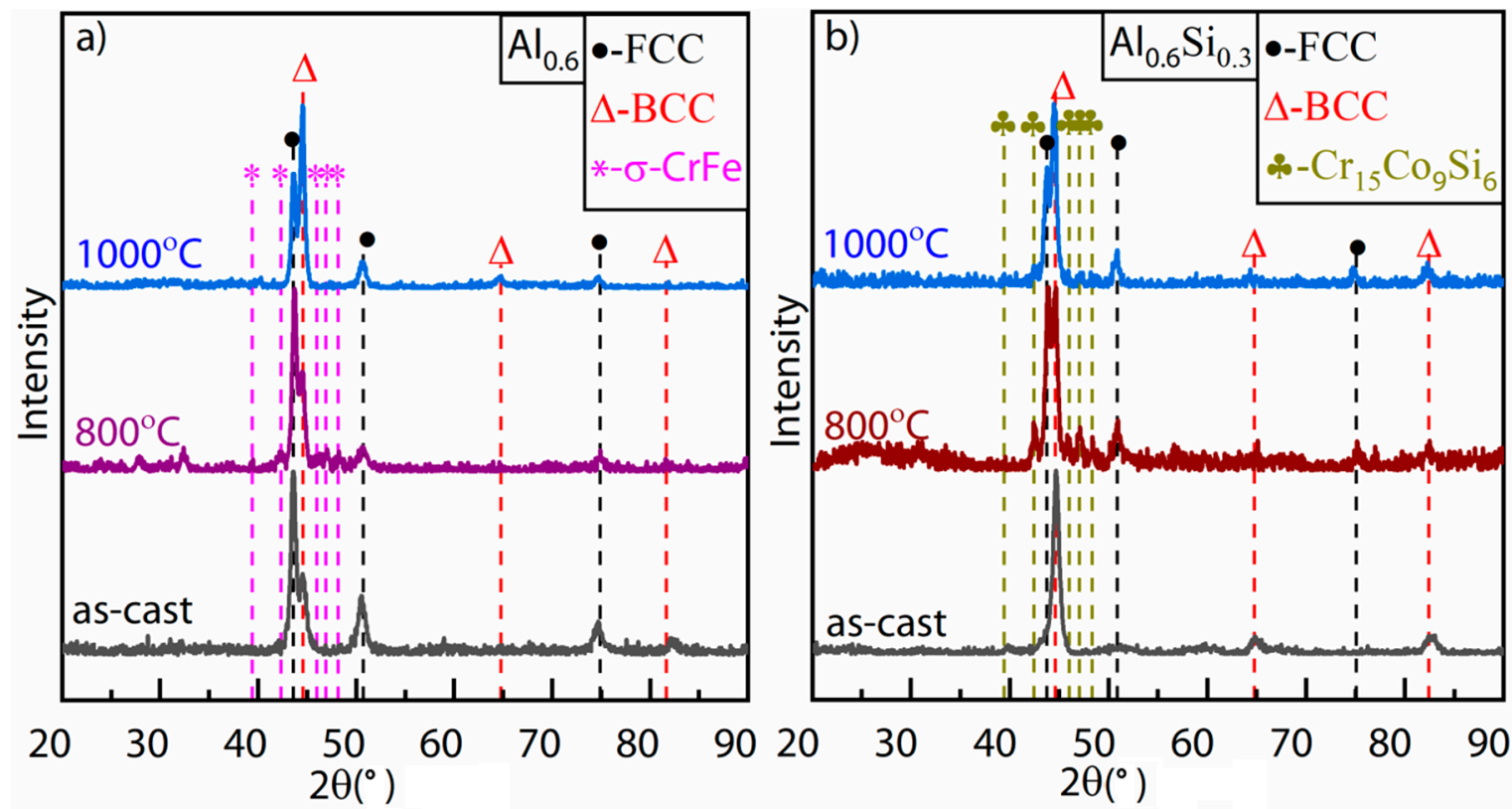

Figure 1. XRD diffraction patterns of $\mathrm{Al}_{0.6}(\mathbf{a})$ and $\mathrm{Al}_{0.6} \mathrm{Si}_{0.3}(\mathbf{b})$ after the oxidation tests at $\mathrm{T}=800{ }^{\circ} \mathrm{C}$, $\mathrm{T}=900{ }^{\circ} \mathrm{C}$ and $\mathrm{T}=1000^{\circ} \mathrm{C}$.

Figure 2 shows a BSE scanning electron microscopy (SEM)-micrograph and the corresponding EDS-mapping results of $\mathrm{Al}_{0.6}$ in its as-cast state. Brighter, coarser columnar grains (marked as CG in Figure 2) and darker areas with a dendritic structure (marked as DS in Figure 2) are clearly recognizable. The darker areas with a dendritic structure comprise fine dark dendrites and fine bright dendrites. The dendritic structure indicates a eutectic solidification during the casting process. The microstructure of $\mathrm{Al}_{0.6}$ is very typical for HEAs with similar chemical compositions as reported in other studies $[12,26,28]$. The EDS-results show that all elements can be detected in both brighter, coarser columnar grains and in darker areas. However, the elements are distributed non-uniformly. The brighter, coarser columnar 
grains are rich in Fe-Co, while the darker areas are rich in Al-Ni. By contrast, $\mathrm{Cr}$ is distributed more uniformly in both brighter, coarser columnar grains and in darker areas. The brighter, coarser columnar grains and the bright fine dendrites in the darker areas exhibit the FCC crystal structure according to the references [12,29], determined by transmission electron microscopy. The dark fine dendrites exhibit the BCC crystal structure [12,17].
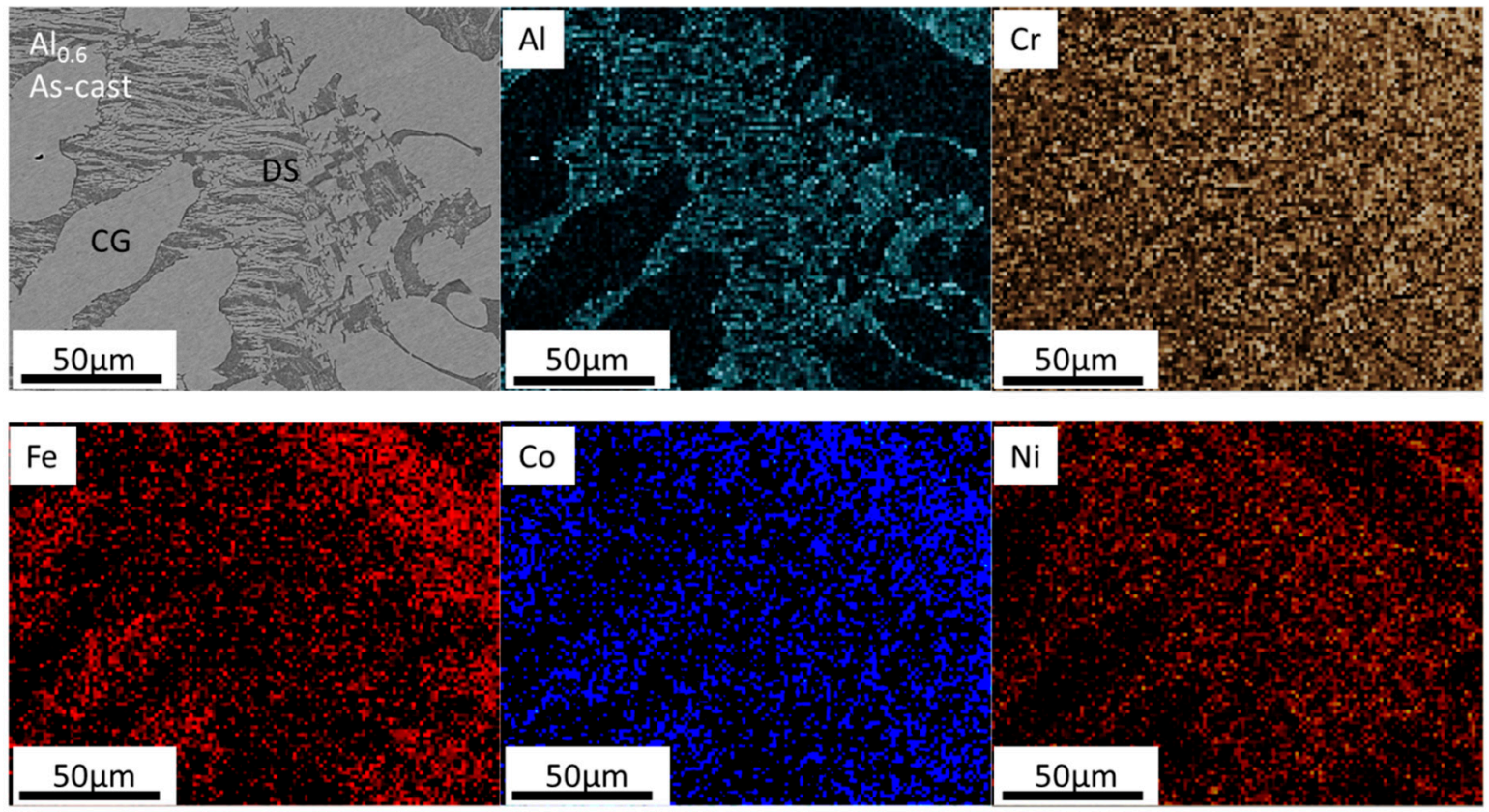

Figure 2. BSE SEM-micrograph and energy dispersive X-ray spectrometer (EDS)-mapping results of $\mathrm{Al}_{0.6}$ in its as-cast state.

Figure 3 shows a BSE SEM-micrograph and EDS-mapping results of $\mathrm{Al}_{0.6} \mathrm{Si}_{0.3}$ in its as-cast state. The microstructure of $\mathrm{Al}_{0.6} \mathrm{Si}_{0.3}$ differs significantly to that of $\mathrm{Al}_{0.6}$. Instead of columnar grains and a dendritic structure, only quasi-equiaxed grains are recognizable, which exhibits a BCC-type structure. The EDS-mapping results show that the elements $\mathrm{Cr}, \mathrm{Fe}, \mathrm{Co}, \mathrm{Ni}$ and $\mathrm{Si}$ are distributed uniformly. By contrast, the element $\mathrm{Al}$ is distributed less uniformly. It is noticeable that the grain boundary is Al-depleted, indicating that the total amount of Al is limited locally. Because the dendritic structure was not formed, it is reasonable to assume that no eutectic-like solidification occurred as a result of the addition of Si.

The X-ray analysis of $\mathrm{Al}_{0.6}$ after the heat treatment at $\mathrm{T}=800{ }^{\circ} \mathrm{C}$ revealed that $\mathrm{Al}_{0.6}$ exhibited mainly the FCC-type phase, but also the BCC-type phase, as shown in Figure 1. However, a change in peak intensity is well recognizable. The peak intensities of the FCC-type phase decrease in comparison with those in an as-cast state, while the intensity of the main peak of the BCC-type phase increases. This indicates that the amount of the FCC-type phase is decreased by the heat treatment while still remaining higher compared to the BCC-type phase. In addition to the FCC-type and BCC-type phases, a new phase is detectable in Figure 1. The peaks of the new phase agree very well with those of $\sigma-\mathrm{CrFe}$ phase. In the two-element system of $\mathrm{Fe}-\mathrm{Cr}$, the $\sigma-\mathrm{CrFe}$ phase is stable only in the temperature range of $\mathrm{T}=500-830^{\circ} \mathrm{C}[30,31]$. By contrast, there is an $\sigma$-phase at room temperature in the heat-treated $\mathrm{Al}_{0.6}$ sample indicating that the $\sigma$-phase in $\mathrm{Al}_{0.6}$ is more stable than that in the Fe-Cr system. The reason for the higher phase stability is assumed to be that the $\sigma$-phase in $\mathrm{Al}_{0.6}$ contains the elements $\mathrm{Co}, \mathrm{Ni}$ and Al. The alloyed $\sigma$-phase is thermodynamically more stable on the one hand and the diffusion of elements in the alloyed $\sigma$-phase is slower on the other hand. 

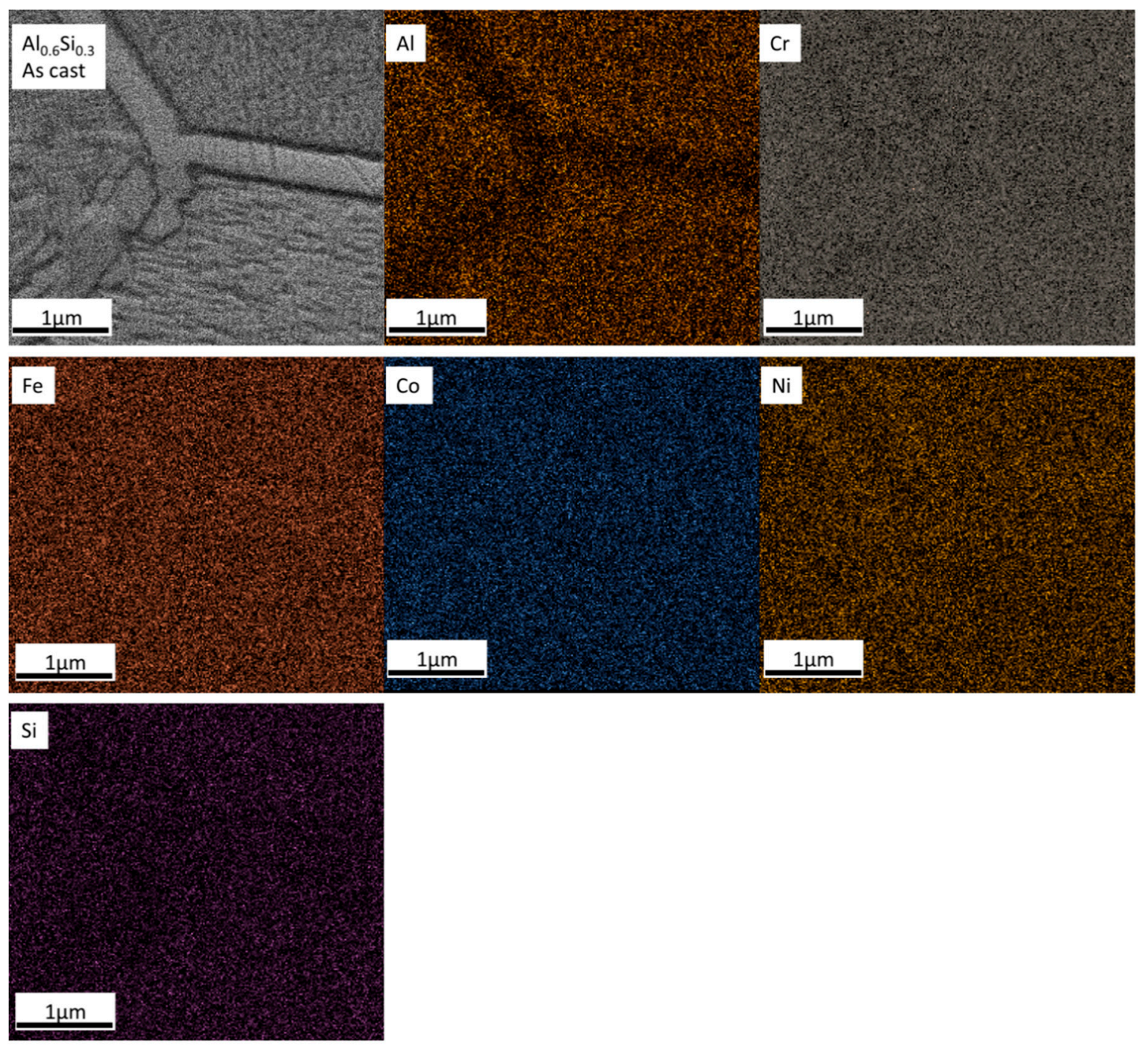

Figure 3. BSE SEM-micrograph and the corresponding EDS-mapping results of $\mathrm{Al}_{0.6} \mathrm{Si}_{0.3}$ in its as-cast state.

Figure 4 shows the high-magnification BSE SEM-micrographs of $\mathrm{Al}_{0.6}$ in its as-cast state and after heat treatment at $\mathrm{T}=800{ }^{\circ} \mathrm{C}$. Compared to its as-cast state, significant changes in the microstructure are recognizable. In an as-cast state, it is recognizable that the brighter, coarser columnar grains became more regular in their shapes as a result of grain growth. The original dendrite structure (DS) becomes unrecognizable. The bright fine dendrite grew together in many locations. The largest change in the brighter, coarser grains is that dark needle-like precipitates are well recognizable under high amplification. The dark color of the precipitates indicates that these precipitates are rich in Al. It was demonstrated that these precipitates exhibit BCC-type AlNi phase [32]. This explains why the main intensity of the BCC phase increased in the X-ray pattern. 


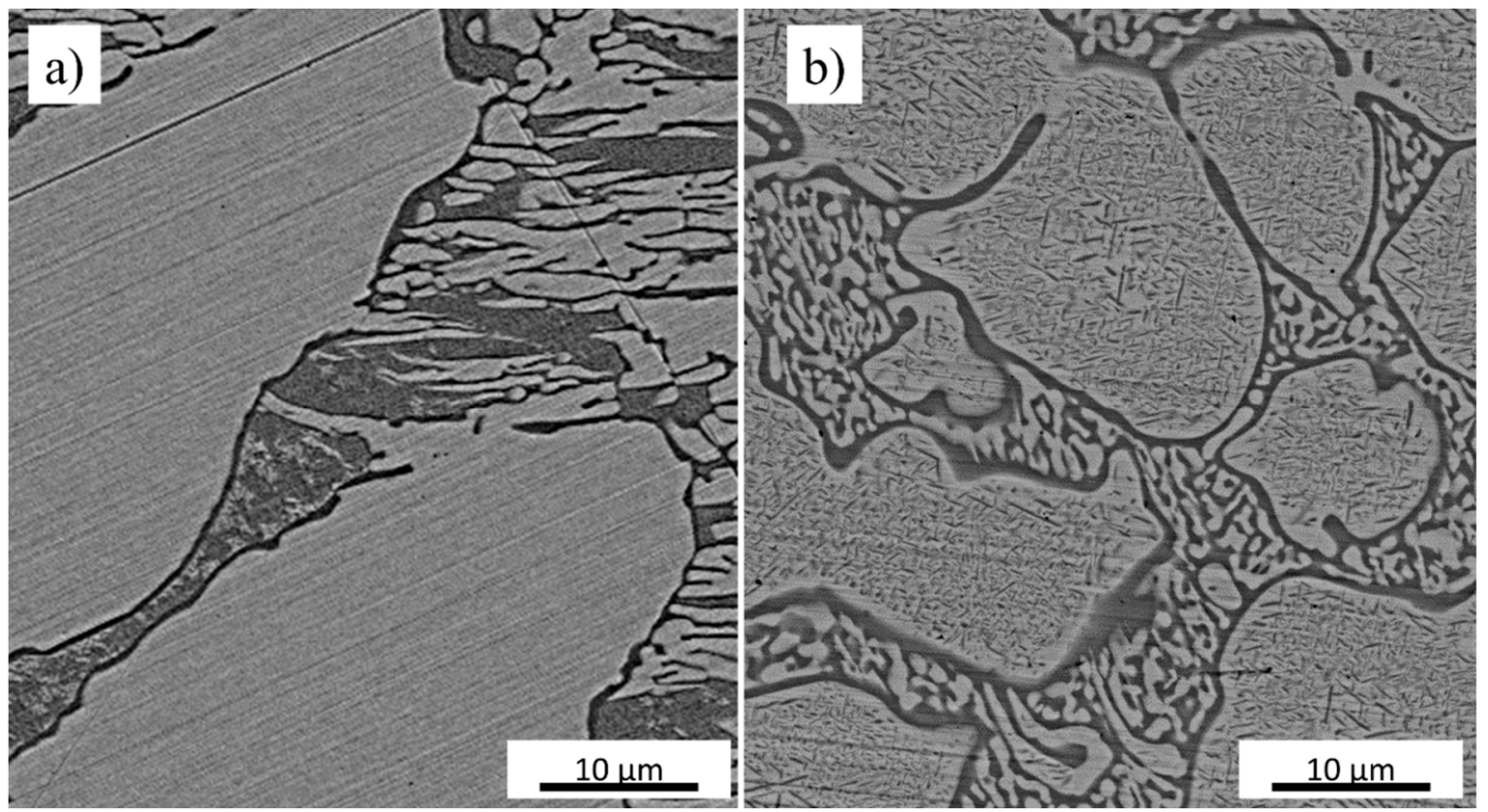

Figure 4. High-magnification $\mathrm{BSE}$ SEM-micrographs of $\mathrm{Al}_{0.6}$ in its as-cast state (a) and after heat treatment at $\mathrm{T}=800{ }^{\circ} \mathrm{C}(\mathbf{b})$.

Figure 5 shows BSE SEM-micrographs and an EDS map scan of $\mathrm{Al}_{0.6}$ after heat treatment at $\mathrm{T}=800{ }^{\circ} \mathrm{C}$. The elements are distributed more non-uniformly compared to an as-cast state. It is recognizable that the FCC-type columnar grain is still rich in Fe-Co, while the BCC-type black grain boundary is rich in $\mathrm{Al}-\mathrm{Ni}$. It should be noted that in the original dendrite structure area some bright particles are rich in Cr. Considering the XRD result shown in Figure 1, the particles should correspond to $\sigma-\mathrm{CrFe}$ phase. The columnar grain also shows needle-like precipitates, but it is hard to testify the element composition due to the low magnification of the picture.
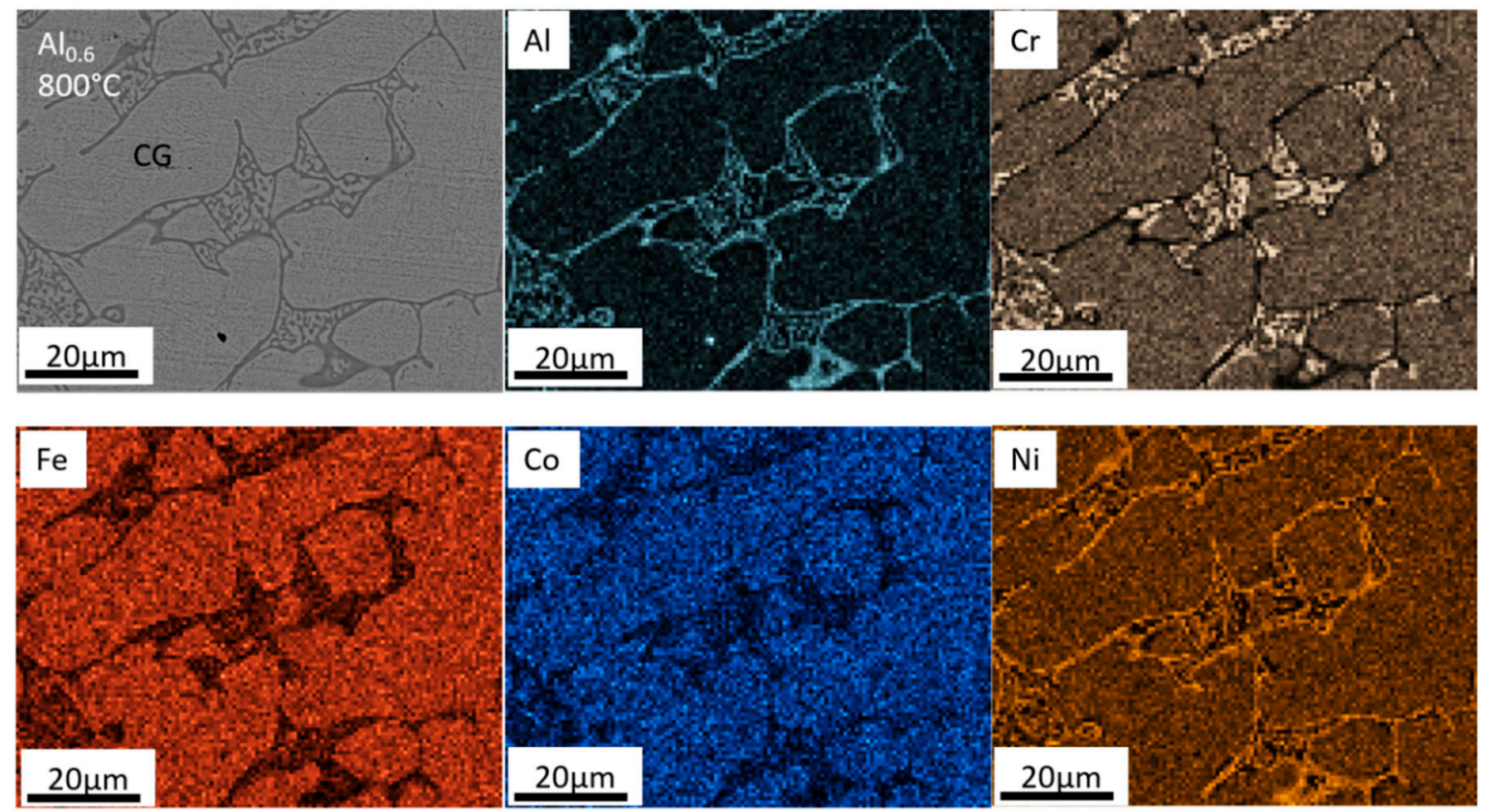

Figure 5. BSE SEM-micrographs and EDS map scan of $\mathrm{Al}_{0.6}$ after heat treatment at $\mathrm{T}=800{ }^{\circ} \mathrm{C}$.

The X-ray analysis of $\mathrm{Al}_{0.6} \mathrm{Si}_{0.3}$ after the heat treatment at $\mathrm{T}=800{ }^{\circ} \mathrm{C}$ revealed that the FCC-type phase precipitated from the BCC-type phase and exhibited a nearly equivalent intensity compared 
to the BCC phase, as shown in Figure 1. This means that a phase transformation happened during the heat treatment. This is probably a result of the metastable state of the $\mathrm{Al}_{0.6} \mathrm{Si}_{0.3}$ alloy due to the as-cast conditions. A similar phenomenon of phase transformation from a BCC to FCC was found by Wen et al. [33]. In addition to the FCC-type and BCC-type phases, a $\mathrm{Cr}_{15} \mathrm{Cog}_{9} \mathrm{Si}_{6}$ phase was detected. The $\mathrm{Cr}_{15} \mathrm{Co}_{9} \mathrm{Si}_{6}$ phase is a stable and brittle phase even for elevated temperatures of up to $\mathrm{T}=1000{ }^{\circ} \mathrm{C}$. It was also reported by Fedorov et al. [34] who identified that the $\mathrm{Cr}_{15} \mathrm{Co}_{9} \mathrm{Si}_{6}$ phase formed in Cobalt-based metallic glass at around $\mathrm{T}=550{ }^{\circ} \mathrm{C}$. The BSE SEM-micrographs and EDS map scan of $\mathrm{Al}_{0.6} \mathrm{Si}_{0.3}$ after the heat treatment at $\mathrm{T}=800{ }^{\circ} \mathrm{C}$ is shown in Figure 6 . In order to observe the fine structure of the alloy, the measurements were taken with a high-magnification micrograph, which produces a map scan with a low resolution. Compared to the as-cast state, there are no distinguishable quasi-equiaxed grains. However, two coexisting phases with different contrasts are observed in the morphology. The EDS-mapping results show that only Fe and Co were distributed uniformly. The other elements were distributed non-uniformly. The brighter, Cr-rich area was reported to be FCC-type [16] while the darker phase, which is rich in Al-Ni, remained BCC-type. This kind of microstructure indicates that the FCC-type phase emerged through the heat treatment of a BCC-type phase. Si was distributed locally in some $\mathrm{Cr}$-rich areas. From the XRD result in Figure 1 , it can be deduced that the Si-rich phase is a $\mathrm{Cr}_{15} \mathrm{Co}_{9} \mathrm{Si}_{6}$ phase.
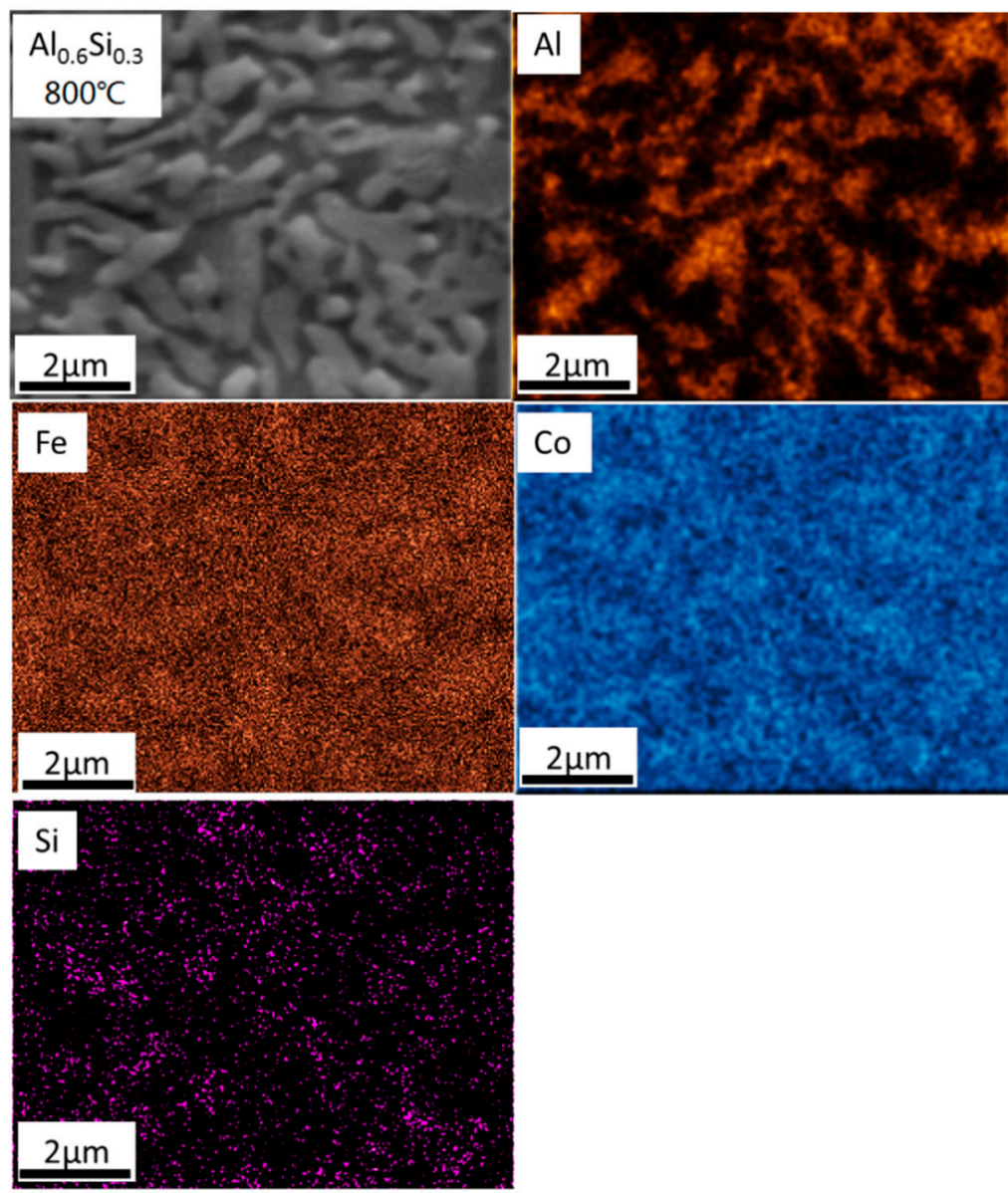

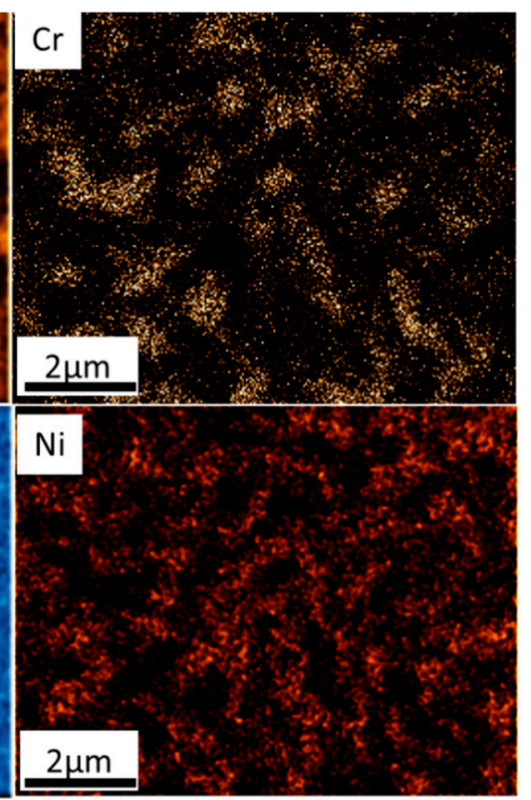

$2 \mu \mathrm{m}$

Figure 6. BSE SEM-micrographs and EDS map scan of $\mathrm{Al}_{0.6} \mathrm{Si}_{0.3}$ after heat treatment at $\mathrm{T}=800{ }^{\circ} \mathrm{C}$.

Compared to the $\mathrm{Al}_{0.6}$ sample after the heat treatment at $\mathrm{T}=800^{\circ} \mathrm{C}$, which is shown in Figure 1 , the X-ray analysis after the heat treatment at $\mathrm{T}=1000^{\circ} \mathrm{C}$ shows a higher percentage of BCC-type phase in $\mathrm{Al}_{0.6}$ in comparison to FCC-type phase. This indicates that the amount of the FCC-type phase is further decreased by the heat treatment at higher temperature. Additionally, the $\sigma-\mathrm{CrFe}$ phase is no longer detectable. Due to the fact, $\sigma-\mathrm{CrFe}$ phase is only stable with the temperature range between 
$\mathrm{T}=500-830{ }^{\circ} \mathrm{C}[30,31]$, it is assumed that the phase dissolved in the alloy during heat treatment of $\mathrm{T}=1000^{\circ} \mathrm{C}$. This phenomenon was also found by other researchers, for instance in [35], where the $\sigma$-CrFe phase dissolved into BCC phase above $\mathrm{T}=975^{\circ} \mathrm{C}$ in some high-entropy alloys. The BSE SEM-micrographs and EDS map scan of $\mathrm{Al}_{0.6}$ after the heat treatment at $\mathrm{T}=1000^{\circ} \mathrm{C}$ are illustrated in Figure 7. Compared to the sample heat-treated at $\mathrm{T}=800{ }^{\circ} \mathrm{C}$, it is obvious that the brighter, coarser columnar grains grew more regularly, and the dark needle-like precipitates grew due to the higher temperature. The EDS-mapping results show that the FCC-type columnar grain is rich in Fe-Co-Cr, while the BCC-type black grain boundaries and needle-like precipitates are rich in Al-Ni. This could explain why the main intensity of the BCC phase is higher in the X-ray pattern. Furthermore, the $\sigma-\mathrm{CrFe}$ phase, which was found at $\mathrm{T}=800{ }^{\circ} \mathrm{C}$ (as shown in Figure 5), is no longer observed. This is also consistent with the XRD results.
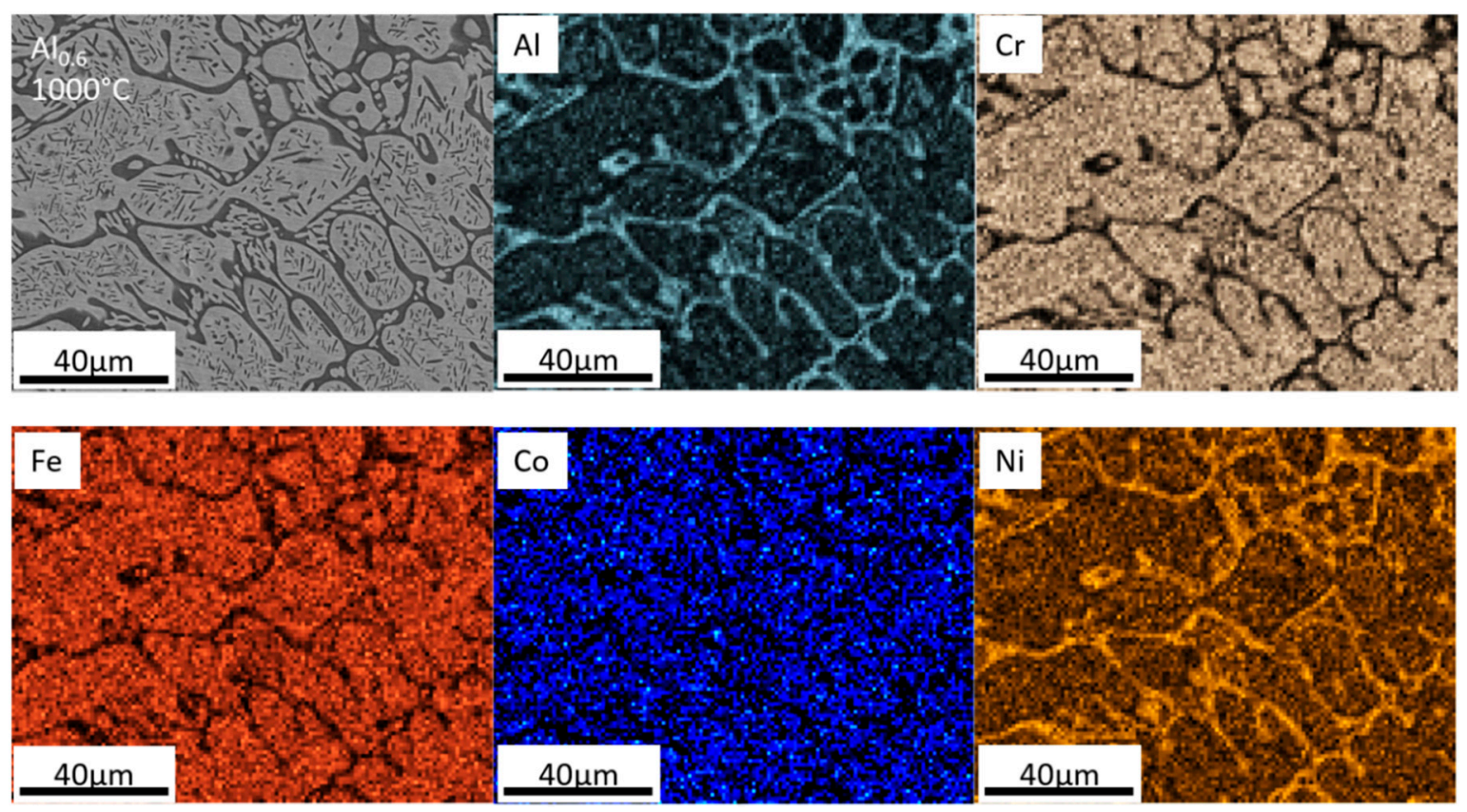

Figure 7. BSE SEM-micrographs and EDS map scan of $\mathrm{Al}_{0.6}$ after heat treatment at $\mathrm{T}=1000{ }^{\circ} \mathrm{C}$.

The X-ray analysis of $\mathrm{Al}_{0.6} \mathrm{Si}_{0.3}$ after the heat treatment at $\mathrm{T}=1000{ }^{\circ} \mathrm{C}$ shows a similar phase composition as for $\mathrm{T}=800{ }^{\circ} \mathrm{C}$, shown in Figure 1 . The main difference is that the $\mathrm{Cr}_{15} \mathrm{Cog}_{9} \mathrm{Si}_{6}$ phase decreased. The BSE SEM-micrographs and EDS map scan of $\mathrm{Al}_{0.6} \mathrm{Si}_{0.3}$ after the heat treatment at $\mathrm{T}=1000{ }^{\circ} \mathrm{C}$ are shown in Figure 8 . Compared to $\mathrm{T}=800{ }^{\circ} \mathrm{C}$, a coarser microstructure and a more non-uniform elemental distribution were observed. The brighter FCC-type phase is rich in Fe-Co-Cr, while the darker BCC-type phase is still rich in Al-Ni. Si is also distributed locally in the Cr-rich area. This observation is supported by the XRD results. 

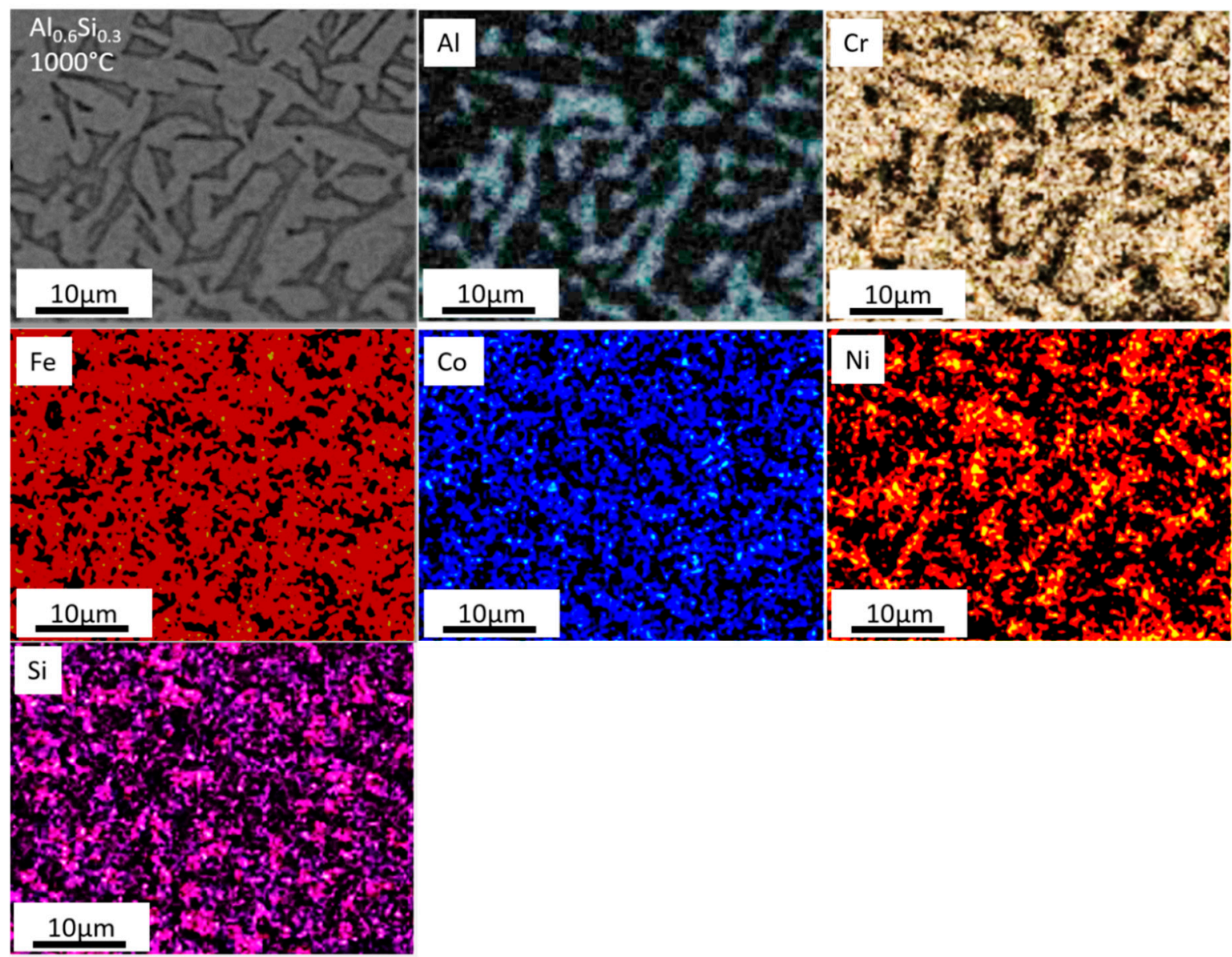

Figure 8. BSE SEM-micrographs and EDS map scan of $\mathrm{Al}_{0.6} \mathrm{Si}_{0.3}$ after heat treatment at $\mathrm{T}=1000{ }^{\circ} \mathrm{C}$.

\subsection{Young's Modulus and Hardness}

In order to investigate the mechanical properties of $\mathrm{Al}_{0.6}$ and $\mathrm{Al}_{0.6} \mathrm{Si}_{0.3}$ alloys, Vickers hardness was measured with a load of $\mathrm{F}=49.1 \mathrm{~N}(5 \mathrm{~kg})$. The hardness indentation images of the $\mathrm{Al}_{0.6}$ alloy are shown in Figure 9. Table 2 shows the hardness of $\mathrm{Al}_{0.6}$ in its as-cast state and heat-treated at $\mathrm{T}=800{ }^{\circ} \mathrm{C}$ and $\mathrm{T}=1000{ }^{\circ} \mathrm{C}$. The sample of $\mathrm{Al}_{0.6}$ heat-treated at $\mathrm{T}=800{ }^{\circ} \mathrm{C}$ exhibited the highest hardness value, which is almost 1.4 times higher than the hardness of the other $\mathrm{Al}_{0.6}$ samples. On the other hand, the hardness values of the as-cast sample and of the heat-treated sample at $\mathrm{T}=1000{ }^{\circ} \mathrm{C}$ were nearly equivalent. This is attributed to the precipitation of the $\sigma-\mathrm{CrFe}$ phase (as shown in Figure 1) at $\mathrm{T}=800{ }^{\circ} \mathrm{C}$, since the $\sigma-\mathrm{CrFe}$ phase is hard and thereby affects the sample's hardness by dispersion in a matrix finely distributed.
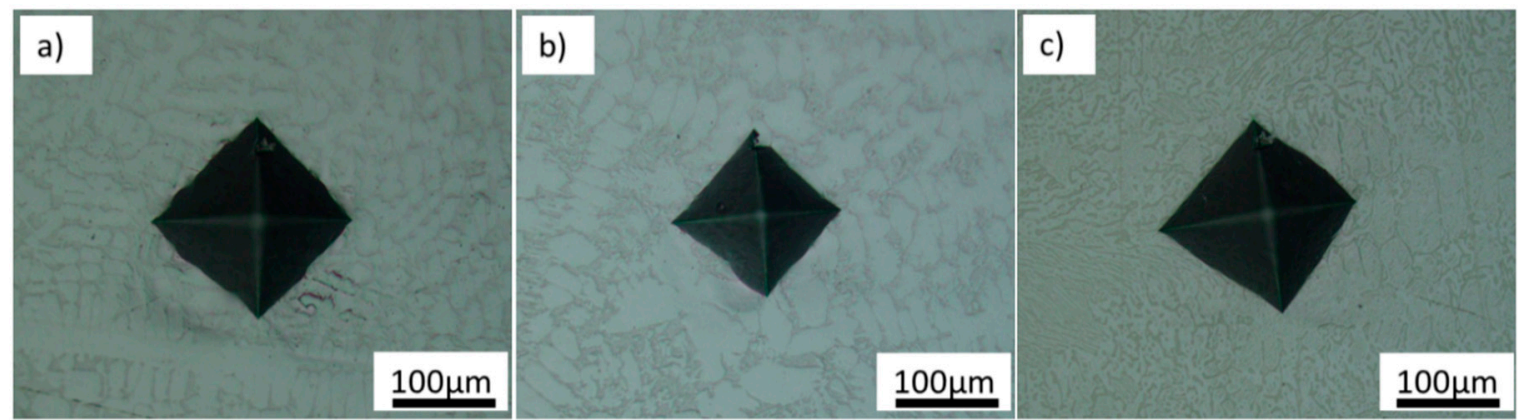

Figure 9. The hardness indentation images of $\mathrm{Al}_{0.6}$ : (a) as-cast, $(\mathbf{b})$ heat-treated at $\mathrm{T}=800{ }^{\circ} \mathrm{C}$ and (c) heat-treated at $\mathrm{T}=1000^{\circ} \mathrm{C}$. 
Table 2. Properties of $\mathrm{Al}_{0.6}$ high-entropy alloys.

\begin{tabular}{cccccccc}
\hline Sample & $\mathbf{H V}_{\mathbf{5}}$ & $\mathbf{H V}_{\mathbf{0 . 1}}$ & $\mathbf{E}_{\mathbf{I T}} / \mathbf{G P a}$ & $\mathbf{E} / \mathbf{G P a}$ & $\mathbf{W}_{\mathbf{e}} / \mathbf{n J}$ & $\mathbf{W}_{\mathbf{p}} / \mathbf{n J}$ & $\mathbf{W}_{\mathbf{p}} /\left(\mathbf{W}_{\mathbf{e}}+\mathbf{W}_{\mathbf{p}}\right)$ \\
\hline $\mathrm{Al}_{0.6}$-as-cast & $245 \pm 21$ & $269 \pm 25$ & $158 \pm 10$ & $174 \pm 12$ & 186 & 1115 & $85.7 \%$ \\
$\mathrm{Al}_{0.6}-800^{\circ} \mathrm{C}$ & $338 \pm 30$ & $363 \pm 39$ & $155 \pm 11$ & $170 \pm 12$ & 229 & 882 & $79.4 \%$ \\
$\mathrm{Al}_{0.6}-1000^{\circ} \mathrm{C}$ & $241 \pm 17$ & $265 \pm 20$ & $152 \pm 8$ & $167 \pm 9$ & 210 & 1140 & $84.4 \%$ \\
\hline
\end{tabular}

Figure 10 shows the force-displacement curves of the $\mathrm{Al}_{0.6}$ alloy as well as the elastic work $\left(\mathrm{W}_{\mathrm{e}}\right)$ and plastic work $\left(\mathrm{W}_{\mathrm{p}}\right)$ during the indentation test. Young' modulus and the percentage of plastic work during the indentation test are summarized in Table 2 as well. All of the three samples exhibit similar Young's modulus values. The largest difference is the $W_{p} /\left(W_{e}+W_{p}\right)$ value, for which that the sample at $\mathrm{T}=800^{\circ} \mathrm{C}$ had the smallest value. This means that the presence of the $\sigma$-CrFe phase causes a decrease in the plastic work, indicating a decreasing toughness of the alloy.
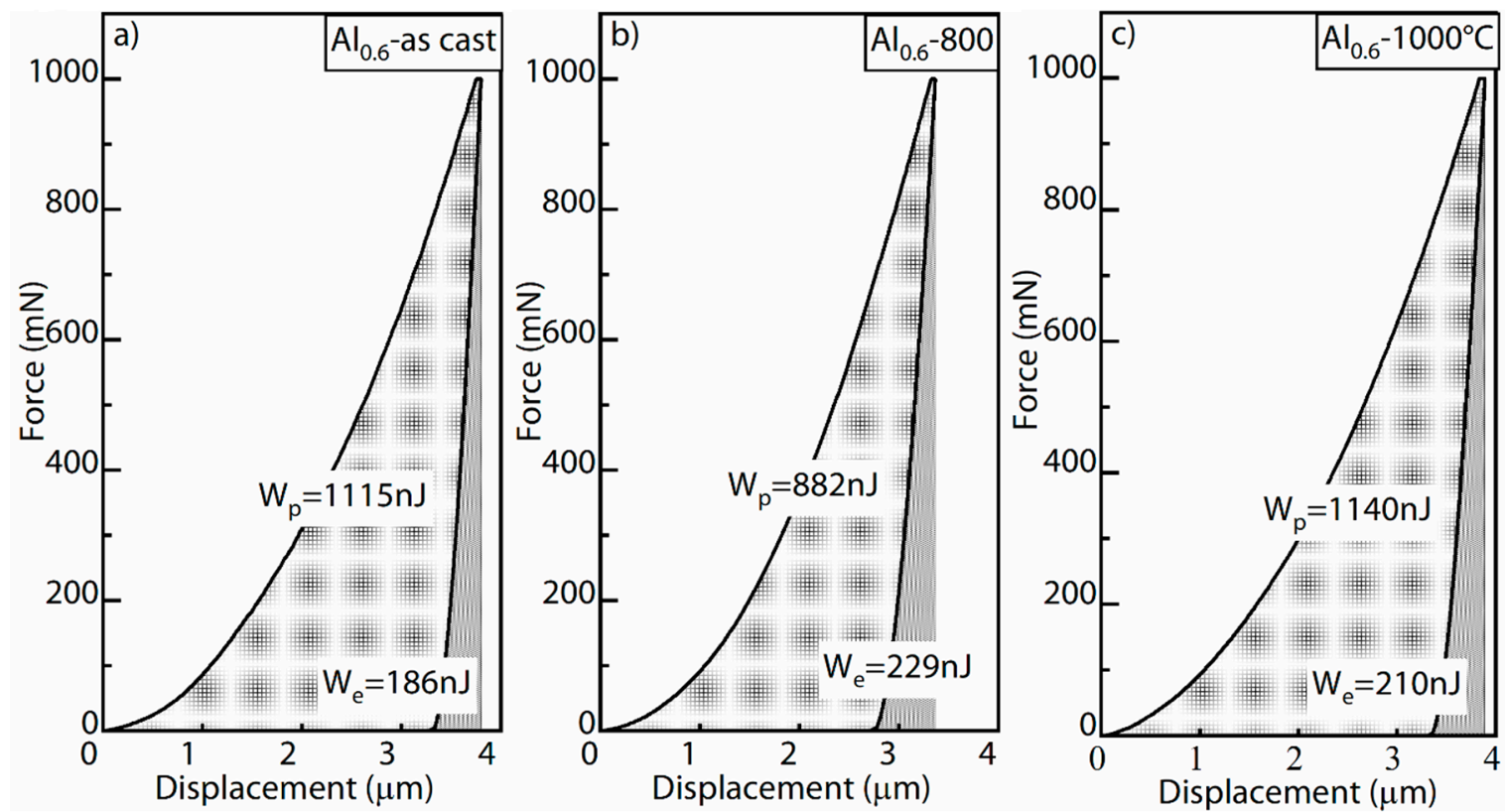

Figure 10. Force-displacement curves of $\mathrm{Al}_{0.6}$ : (a) as-cast, (b) heat-treated at $\mathrm{T}=800{ }^{\circ} \mathrm{C}$ and (c) heat-treated at $\mathrm{T}=1000{ }^{\circ} \mathrm{C}$.

The hardness indentation images of the $\mathrm{Al}_{0.6} \mathrm{Si}_{0.3}$ alloy are shown in Figure 11. The properties of the $\mathrm{Al}_{0.6} \mathrm{Si}_{0.3}$ alloy and force-displacement curves are shown in Table 3 and Figure 12. Compared to $\mathrm{Al}_{0.6}, \mathrm{Al}_{0.6} \mathrm{Si}_{0.3}$ exhibited a higher hardness and a higher Young's modulus due to the Si-alloying effect. The as-cast alloy exhibited the highest hardness and the lowest $W_{p} /\left(W_{e}+W_{p}\right)$ value. As the sample was heat-treated at $\mathrm{T}=800^{\circ} \mathrm{C}$ and $\mathrm{T}=1000{ }^{\circ} \mathrm{C}$, both the hardness and the percentage of plastic work changed gradually. At $\mathrm{T}=800^{\circ} \mathrm{C}$, a large amount of the FCC phase precipitated from the BCC phase, resulting in a decreased hardness and an increased toughness. As the temperature increased to $\mathrm{T}=1000^{\circ} \mathrm{C}$, the coarser microstructure resulting from the grain growth further decreased the hardness and increased the toughness of the alloy.

Table 3. Properties of $\mathrm{Al}_{0.6} \mathrm{Si}_{0.3}$ high-entropy alloys.

\begin{tabular}{|c|c|c|c|c|c|c|c|}
\hline Sample & $\mathrm{HV}_{5}$ & $\mathrm{HV}_{0.1}$ & EIT/GPa & E/GPa & $\mathrm{W}_{\mathrm{e}} / \mathrm{pJ}$ & $\mathrm{W}_{\mathrm{p}} / \mathrm{pJ}$ & $W_{p} /\left(W_{e}+W_{p}\right)$ \\
\hline $\mathrm{Al}_{0.6} \mathrm{Si}_{0.3}$-as-cast & $616 \pm 54$ & $669 \pm 47$ & $176 \pm 12$ & $194 \pm 14$ & 260 & 640 & $71.1 \%$ \\
\hline $\mathrm{Al}_{0.6} \mathrm{Si}_{0.3}-800^{\circ} \mathrm{C}$ & $558 \pm 50$ & $605 \pm 39$ & $166 \pm 6$ & $183 \pm 7$ & 255 & 711 & $73.6 \%$ \\
\hline $\mathrm{Al}_{0.6} \mathrm{Si}_{0.3}-1000^{\circ} \mathrm{C}$ & $425 \pm 39$ & $459 \pm 56$ & $162 \pm 6$ & $178 \pm 7$ & 243 & 807 & $76.8 \%$ \\
\hline
\end{tabular}




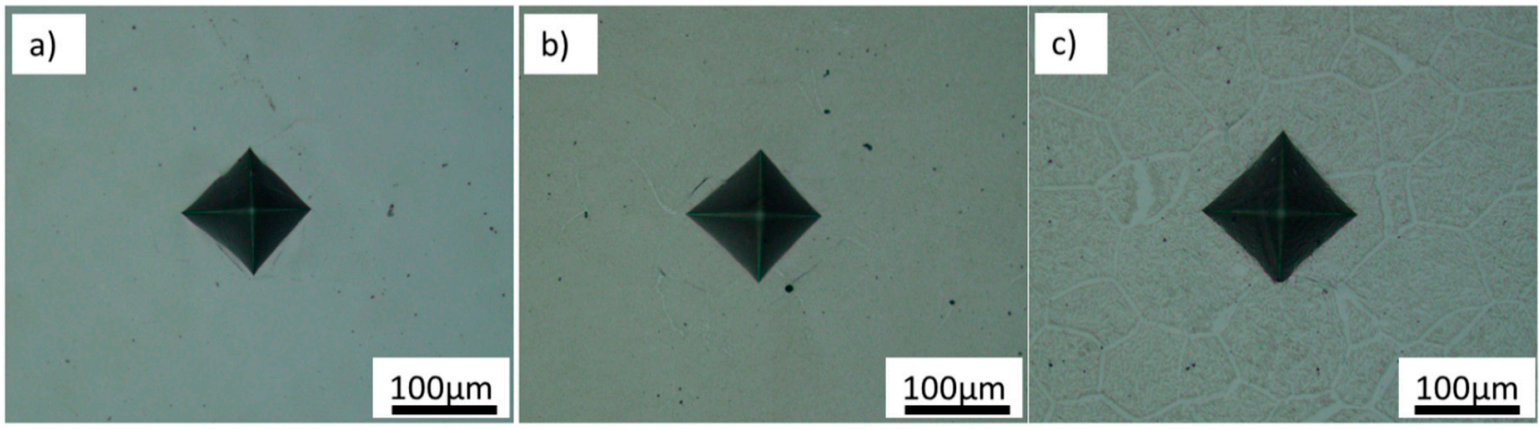

Figure 11. The hardness indentation images of $\mathrm{Al}_{0.6} \mathrm{Si}_{0.3}$ : (a) as-cast $(\mathbf{b})$ heat-treated at $\mathrm{T}=800{ }^{\circ} \mathrm{C}$ and (c) heat-treated at $\mathrm{T}=1000{ }^{\circ} \mathrm{C}$.
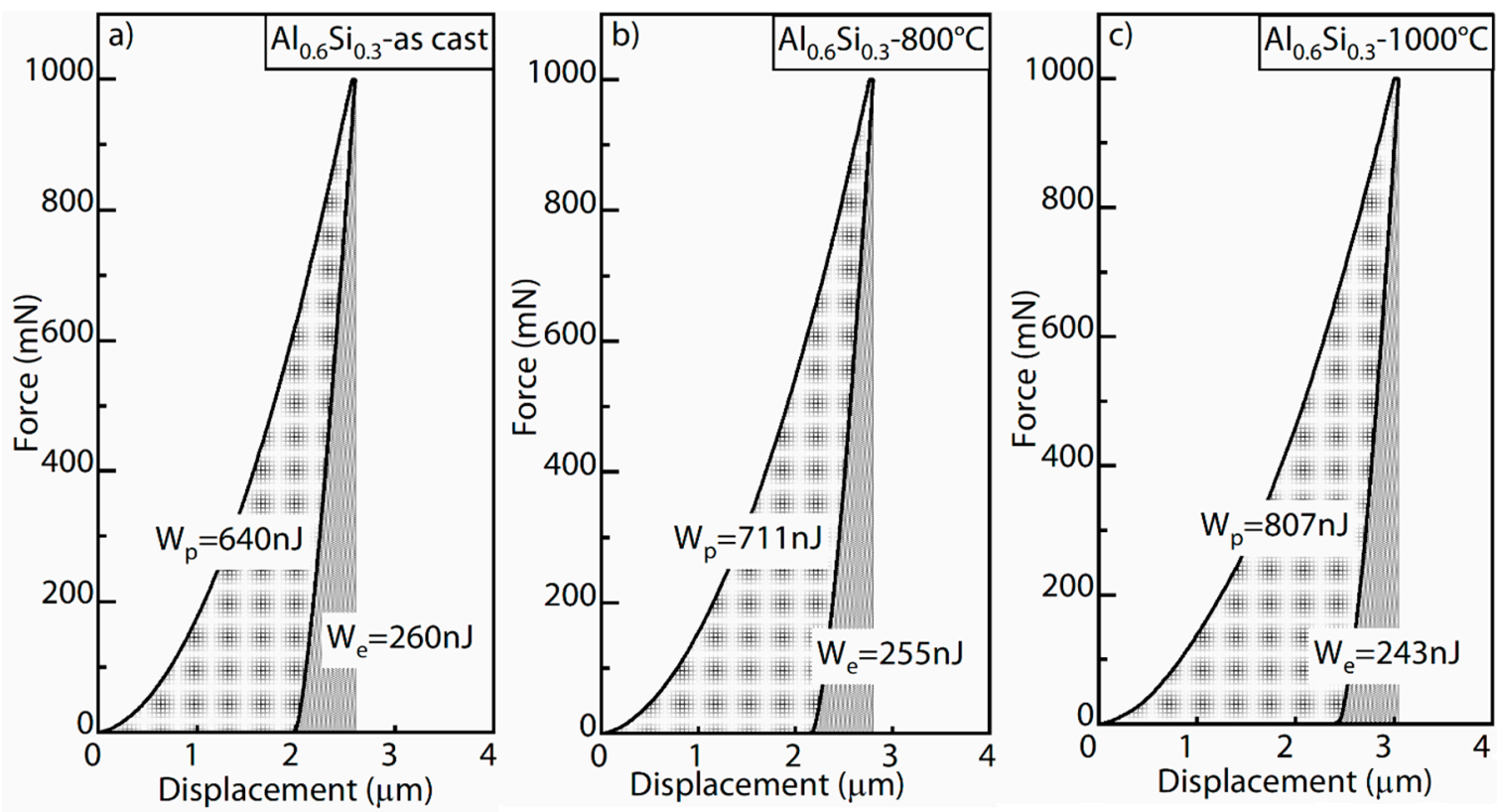

Figure 12. Force-displacement curves of $\mathrm{Al}_{0.6} \mathrm{Si}_{0.3}$ : (a) as-cast (b) heat-treated at $\mathrm{T}=800{ }^{\circ} \mathrm{C}$ and (c) heat-treated at $\mathrm{T}=1000{ }^{\circ} \mathrm{C}$.

\section{Conclusions}

This study investigated the heat treatment effect on the microstructure, phase composition and mechanical properties of $\mathrm{Al}_{0.6} \mathrm{CrFeCoNi}$ and $\mathrm{Al}_{0.6} \mathrm{CrFeCoNiSi}_{0.3}$ alloys after heat treatment at $\mathrm{T}=800^{\circ} \mathrm{C}$ and $1000^{\circ} \mathrm{C}$. The following conclusions can be made:

(1) In its as-cast state, the $\mathrm{Al}_{0.6} \mathrm{CrFeCoNi}$ alloy exhibited dual phases consisting of a $\mathrm{BCC}$ and a FCC phase. The $\mathrm{Al}_{0.6} \mathrm{CrFeCoNi}$ alloy exhibited a single $\mathrm{BCC}$ phase due to the Si-alloying effect. Si-alloying increased the hardness of the $\mathrm{Al}_{0.6} \mathrm{CrFeCoNi}$ alloy for all the samples.

(2) For the $\mathrm{Al}_{0.6} \mathrm{CrFeCoNi}$ alloy, the heat treatment at $\mathrm{T}=800{ }^{\circ} \mathrm{C}$ and $\mathrm{T}=1000{ }^{\circ} \mathrm{C}$ caused a phase transformation from a FCC-type to a BCC-type phase and coarsened the microstructure. A BCC-type needle-like precipitate started to emerge in the microstructure at $\mathrm{T}=800{ }^{\circ} \mathrm{C}$ and became larger at $\mathrm{T}=1000{ }^{\circ} \mathrm{C}$. The $\sigma-\mathrm{CrFe}$ phase precipitated from the matrix at $\mathrm{T}=800{ }^{\circ} \mathrm{C}$ and disappeared at $\mathrm{T}=1000{ }^{\circ} \mathrm{C}$.

(3) For the $\mathrm{Al}_{0.6} \mathrm{CrFeCoNiSi}_{0.3}$ alloy, the FCC phase and the $\mathrm{Cr}_{15} \mathrm{Co}_{9} \mathrm{Si}_{6}$ phase precipitated at $\mathrm{T}=800{ }^{\circ} \mathrm{C}$. At $\mathrm{T}=1000{ }^{\circ} \mathrm{C}$, the phase composition was similar to that observed at $\mathrm{T}=800{ }^{\circ} \mathrm{C}$, while the microstructure was coarser and the elemental distribution was more non-uniform.

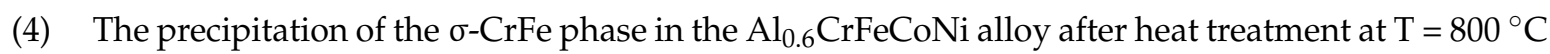
caused an increase in the alloy hardness and a decrease in toughness. The hardness and the 
percentage of plastic work during the indentation test were comparable for the as-cast sample and heat-treated sample at $\mathrm{T}=1000^{\circ} \mathrm{C}$.

(5) The phase transformation from $\mathrm{BCC}$ to $\mathrm{FCC}$ in the $\mathrm{Al}_{0.6} \mathrm{CrFeCoNiSi}_{0.3}$ alloy decreased the hardness and increased the toughness at $\mathrm{T}=800^{\circ} \mathrm{C}$. As the microstructure got coarser, the hardness decreased and the toughness increased further at $\mathrm{T}=1000^{\circ} \mathrm{C}$.

Author Contributions: L.C. and Z.Z. conceived and designed the experiments; L.C. performed the experiments, analyzed the data, and wrote the paper; K.B., L.Z., M.Ö. and T.K. revised the paper; Z.T. and D.H. directed the research and contributed to the discussion and interpretation of the results.

Funding: This research was financially funded by the National Key R\&D Program of China grant number 2017YFB0306100, the National Natural Science Foundation of China grant number 51771005 and The National Natural Science Fund for Innovative Research Groups grant number 51621003. In addition, the authors are also grateful for the financial support by the China Scholarship Council.

Conflicts of Interest: The authors declare no conflict of interest.

\section{References}

1. Yeh, J.-W.; Chen, S.-K.; Lin, S.-J.; Gan, J.-Y.; Chin, T.-S.; Shun, T.-T.; Tsau, C.-H.; Chang, S.-Y. Nanostructured high-entropy alloys with multiple principal elements: Novel alloy design concepts and outcomes. Adv. Eng. Mater. 2004, 6, 299-303. [CrossRef]

2. Reed, R.C.; Tao, T.; Warnken, N. Alloys-by-design: Application to nickel-based single crystal superalloys. Acta Mater. 2009, 57, 5898-5913. [CrossRef]

3. Yeh, A.-C.; Sato, A.; Kobayashi, T.; Harada, H. On the creep and phase stability of advanced Ni-base single crystal superalloys. Mater. Sci. Eng. A 2008, 490, 445-451. [CrossRef]

4. Singh, S.; Wanderka, N.; Murty, B.S.; Glatzel, U.; Banhart, J. Decomposition in multi-component AlCoCrCuFeNi high-entropy alloy. Acta Mater. 2011, 59, 182-190. [CrossRef]

5. Yeh, A.C.; Yang, K.C.; Yeh, J.W.; Kuo, C.M. Developing an advanced Si-bearing DS Ni-base superalloy. J. Alloys Compd. 2014, 585, 614-621. [CrossRef]

6. Zhu, J.M.; Fu, H.M.; Zhang, H.F.; Wang, A.M.; Li, H.; Hu, Z.Q. Microstructure and compressive properties of multiprincipal component AlCoCrFeNiCx alloys. J. Alloys Compd. 2011, 509, 3476-3480. [CrossRef]

7. Couzinié, J.P.; Dirras, G.; Perrière, L.; Chauveau, T.; Leroy, E.; Champion, Y.; Guillot, I. Microstructure of a near-equimolar refractory high-entropy alloy. Mater. Lett. 2014, 126, 285-287. [CrossRef]

8. Chou, Y.L.; Yeh, J.W.; Shih, H.C. Effect of molybdenum on the pitting resistance of Co1.5CrFeNi1.5Ti0.5Mox alloys in chloride solutions. Corrosion 2011, 67, 085002-1-085002-6.

9. Chuang, M.-H.; Tsai, M.-H.; Wang, W.-R.; Lin, S.-J.; Yeh, J.-W. Microstructure and wear behavior of AlxCo1.5CrFeNi1.5Tiy high-entropy alloys. Acta Mater. 2011, 59, 6308-6317. [CrossRef]

10. Chang, S.-Y.; Li, C.-E.; Huang, Y.-C.; Hsu, H.-F.; Yeh, J.-W.; Lin, S.-J. Structural and thermodynamic factors of suppressed interdiffusion kinetics in multi-component high-entropy materials. Sci. Rep. 2014, 4, 4162. [CrossRef] [PubMed]

11. Ma, L.; Li, C.; Jiang, Y.; Zhou, J.; Wang, L.; Wang, F.; Cao, T.; Xue, Y. Cooling rate-dependent microstructure and mechanical properties of $\mathrm{Al}$ x Si $0.2 \mathrm{CrFeCoNiCu} 1-x$ high entropy alloys. J. Alloys Compd. 2017, 694, 61-67. [CrossRef]

12. Ma, L.; Wang, L.; Nie, Z.; Wang, F.; Xue, Y.; Zhou, J.; Cao, T.; Wang, Y.; Ren, Y. Reversible deformation-induced martensitic transformation in $\mathrm{Al}$ 0.6 CoCrFeNi high-entropy alloy investigated by in situ synchrotron-based high-energy X-ray diffraction. Acta Mater. 2017, 128, 12-21. [CrossRef]

13. Wang, P.; Cheng, X.; Cai, H.; Xue, Y.; Zhang, Y. Influence of increasing Al concentration on phase, microstructure and mechanical behaviors of $\mathrm{Ni}_{1.5} \mathrm{CoFeCu}_{1-\mathrm{x}} \mathrm{Al}_{\mathrm{x}} \mathrm{V}_{0.5}$ high entropy alloys. Mater. Sci. Eng. A 2017, 708, 523-536. [CrossRef]

14. Wu, W.-H.; Yang, C.-C.; Yeh, J.-W. Industrial development of high-entropy alloys. Ann. Chim. Sci. Mat. 2006, 31, 737-747. [CrossRef]

15. Hobbs, R.A.; Tin, S.; Rae, C.M.F. A castability model based on elemental solid-liquid partitioning in advanced nickel-base single-crystal superalloys. Metall. Mater. Trans. A 2005, 36, 2761-2773. [CrossRef] 
16. Butler, T.M.; Alfano, J.P.; Martens, R.L.; Weaver, M.L. High-temperature oxidation behavior of Al-Co-Cr-Ni-(Fe or Si) multicomponent high-entropy alloys. JOM 2015, 67, 246-259. [CrossRef]

17. Butler, T.M.; Weaver, M.L. Oxidation behavior of arc melted AlCoCrFeNi multi-component high-entropy alloys. J. Alloys Compd. 2016, 674, 229-244. [CrossRef]

18. Chang, Y.-J.; Yeh, A.-C. The evolution of microstructures and high temperature properties of AlxCo1.5CrFeNi1.5Tiy high entropy alloys. J. Alloys Compd. 2015, 653, 379-385. [CrossRef]

19. Liu, C.M.; Wang, H.M.; Zhang, S.Q.; Tang, H.B.; Zhang, A.L. Microstructure and oxidation behavior of new refractory high entropy alloys. J. Alloys Compd. 2014, 583, 162-169. [CrossRef]

20. Löbel, M.; Lindner, T.; Mehner, T.; Lampke, T. Microstructure and wear resistance of AlCoCrFeNiTi high-entropy alloy coatings produced by HVOF. Coatings 2017, 7, 144. [CrossRef]

21. Löbel, M.; Lindner, T.; Kohrt, C.; Lampke, T. Processing of AlCoCrFeNiTi high entropy alloy by atmospheric plasma spraying. IOP Conf. Ser. Mater. Sci. Eng. 2017, 181, 12015. [CrossRef]

22. Chen, L.; Zhou, Z.; Tan, Z.; He, D.; Bobzin, K.; Zhao, L.; Öte, M.; Königstein, T. High temperature oxidation behavior of $\mathrm{Al} 0.6 \mathrm{CrFeCoNi}$ and $\mathrm{Al} 0.6 \mathrm{CrFeCoNiSi} 0.3$ high entropy alloys. J. Alloys Compd. 2018, 764, 845-852. [CrossRef]

23. Bobzin, K.; Brögelmann, T.; Kruppe, N.C.; Arghavani, M.; Mayer, J.; Weirich, T.E. Plastic deformation behavior of nanostructured CrN/AlN multilayer coatings deposited by hybrid dcMS/HPPMS. Surf. Coat. Technol. 2017, 332, 253-261. [CrossRef]

24. Wang, W.-R.; Wang, W.-L.; Yeh, J.-W. Phases, microstructure and mechanical properties of AlxCoCrFeNi high-entropy alloys at elevated temperatures. J. Alloys Compd. 2014, 589, 143-152. [CrossRef]

25. Uporov, S.; Bykov, V.; Pryanichnikov, S.; Shubin, A.; Uporova, N. Effect of synthesis route on structure and properties of AlCoCrFeNi high-entropy alloy. Intermetallics 2017, 83, 1-8. [CrossRef]

26. Zhou, S.-C.; Zhang, P.; Xue, Y.-F.; Wang, F.-C.; Wang, L.; Cao, T.-Q.; Tan, Z.; Cheng, B.-Y.; Wang, B.-P. Microstructure evolution of $\mathrm{Al} 0.6 \mathrm{CoCrFeNi}$ high entropy alloy powder prepared by high pressure gas atomization. Trans. Nonferrous Met. Soc. China 2018, 28, 939-945. [CrossRef]

27. Kumar, A.; Dhekne, P.; Swarnakar, A.K.; Chopkar, M.K. Analysis of Si addition on phase formation in AlCoCrCuFeNiSix high entropy alloys. Mater. Lett. 2017, 188, 73-76. [CrossRef]

28. Wang, W.-R.; Wang, W.-L.; Wang, S.-C.; Tsai, Y.-C.; Lai, C.-H.; Yeh, J.-W. Effects of Al addition on the microstructure and mechanical property of AlxCoCrFeNi high-entropy alloys. Intermetallics 2012, 26, 44-51. [CrossRef]

29. Yang, T.; Xia, S.; Liu, S.; Wang, C.; Liu, S.; Fang, Y.; Zhang, Y.; Xue, J.; Yan, S.; Wang, Y. Precipitation behavior of AlxCoCrFeNi high entropy alloys under ion irradiation. Sci. Rep. 2016, 6, 32146. [CrossRef] [PubMed]

30. Andersson, J.-O.; Sundman, B. Thermodynamic properties of the Cr Fe system. Calphad 1987, 11, 83-92. [CrossRef]

31. Xiong, W.; Hedström, P.; Selleby, M.; Odqvist, J.; Thuvander, M.; Chen, Q. An improved thermodynamic modeling of the Fe-Cr system down to zero kelvin coupled with key experiments. Calphad 2011, 35, 355-366. [CrossRef]

32. Kao, Y.-F.; Chen, T.-J.; Chen, S.-K.; Yeh, J.-W. Microstructure and mechanical property of as-cast, -homogenized, and -deformed AlxCoCrFeNi $(0 \leq x \leq 2)$ high-entropy alloys. J. Alloys Compd. 2009, 488, 57-64. [CrossRef]

33. Wen, L.H.; Kou, H.C.; Li, J.S.; Chang, H.; Xue, X.Y.; Zhou, L. Effect of aging temperature on microstructure and properties of $\mathrm{AlCoCrCuFeNi}$ high-entropy alloy. Intermetallics 2009, 17, 266-269. [CrossRef]

34. Fedorov, V.A.; Yakovlev, A.V.; Pluzhnikova, T.N. Laws of Changing the Structure and Properties of Metallic Glasses upon Annealing and Loca Mechanical Loading. Russ. Phys. J. 2012, 54, 1006-1011. [CrossRef]

35. Zhang, Y.; Zuo, T.T.; Tang, Z.; Gao, M.C.; Dahmen, K.A.; Liaw, P.K.; Lu, Z.P. Microstructures and properties of high-entropy alloys. Prog. Mater Sci. 2014, 61, 1-93. [CrossRef]

(C) 2018 by the authors. Licensee MDPI, Basel, Switzerland. This article is an open access article distributed under the terms and conditions of the Creative Commons Attribution (CC BY) license (http:/ / creativecommons.org/licenses/by/4.0/). 